\title{
The core of affects: namer and named in Bahia (Brazil)
}

Jõ̃o De Pina-Cabral University of Kent

\begin{abstract}
This article is a study of personal naming using drawings made by secondary school students from two small towns in coastal Bahia (Brazil) of the persons who gave them their names. The article explores the relation between namer and named as one of continued identity created by imaginative processes of surrogation akin to pretend-play. In early ontogeny, the person is constituted through a series of mutualities of being that come to constitute a core of affects. The article aims to contribute towards a better understanding of the processes of constitution of personhood in the context of human relatedness.
\end{abstract}

[T] he poet works upon the core of affects.

Gilberto Gil

Gilberto Gil's evocative sentence could be read as an aporia: it starts by proposing that there is a zone in each one of us where our affects assume greater consistency, but then it suggests that, since this core is something that one can work upon, the historical process of personal constitution is a lifelong venture where poets, for instance, can intervene. In this article, I aim to explore this insight, suggesting that there is no real contradiction between the two readings. The world around us reflects back to us constantly the relations that structured historically our constitution as dividual persons: ${ }^{1}$ our personal names can be taken as one of the principal ways in which the surrounding world echoes back our constitutive affects in a dynamic process where personal plurality and personal singularity creatively combine. The article explores this question in an effort to contribute towards an understanding of personhood and human relatedness.

Recently, Marshall Sahlins attempted to bring together the long and complex history of empirical research and critical analysis that is enshrined in the anthropological tradition of kinship studies. He coined the expression mutualities of being to refer to the empirical observation that 'kinsmen are persons who belong to one another, who are members of one another, who are co-present in each other, whose lives are joined and interdependent' (Sahlins 2011a: 11; see also 2011b). This mutuality arises from the fact that human attachment is anterior to the formation of the human subject. In early infancy, intersubjectivity is a condition for subjectivity to arise, not the contrary (see 
Bråten 1998). ${ }^{2}$ This means that the condition of being-in-relation predates any specific relation between determinable persons. To put it in Judith Butler's recent words, for example, " $[\mathrm{P}]$ rimary relations precede the formation of what we call an "ego" and even the "ego" is understood primarily as consisting of modes of "ego relatedness" , (2012: 113).

The primary implication of this notion of relatedness for our area of studies is that each one of us carries a pre-history, as it were. There is in our personhood a historicity, an immanent pastness (see Martins 1974). And here we encounter yet another paradox, for the pastness of personhood cannot be bounded by personal ontogeny in the sense that, if the person emerges from attachments that predate the person's constitution (an anterior alterity), then whilst the child is new, the 'other' is not. ${ }^{3}$ And, as Donald Winnicott (1971) came to understand, it is never only 'one' other. ${ }^{4}$

In short, since there is a foundational alterity in personhood, the notion that there is a clean beginning to it makes no sense. Not only do persons emerge from the embrace of earlier persons in child-rearing, but they also see themselves as causally linked to earlier persons (that which anthropologists usually refer to as 'filiation'). Such a process is not a generalized condition; rather, it is grounded on specific human relations whose history is unique in the case of each one of us: our history of personal ontogeny. Whilst the history of each one's existence as a determinable person is immersed in the long history of sociality, none of us can be reduced to a simple manifestation of an overarching totality - our namers are particular others, not a generic other. ${ }^{5}$

Personhood, thus, is a historical transformation that embraces much more than just the child and the persons who nurture it, encompassing from the beginning their common living environment. Over the years, as I studied household and family formation in Portugal (Pina-Cabral 2003) and then among the Eurasians of Macau (PinaCabral 2002a), I came to identify the existence of manners of engagement with pastness that correspond to these processes of co-presence in personal constitution. I call the specific instantiations of this pastness continued identities. Each person carries a plurality of them at the core of his or her affects. They are a phenomenon of memory, of course, but not in the representationist sense of memory that is enshrined in the sociological tradition; rather, in the neurophenomenological sense that sees long-term memory ultimately as a physiological process built on personal ontogeny, as explored, for example, by Eric Kandel (2006) in his well-known scientific biography.

I believe that the ethnographic material I have been collecting concerning naming processes among Portuguese-speakers (Pina-Cabral 2010c; 2012) allows us to extend the insight that such continued identities are not merely mental processes but are inscribed in the world around us (in things, spaces, words, narratives, dictionaries, etc.) - they inhere in the world we cohabit. ${ }^{6}$ As an example of this, I argue that the way in which each one of us 'works upon' his or her personal name is a constant process of actualization and revalidation of his or her continued identities.

The present article, whilst focusing on ethnographic material collected among secondary school students from two small towns of southern coastal Bahia (Brazil), aims to shed light more generally on the new approaches to personhood and kinship that have been emerging of late in a broad interdisciplinary dialogue that goes way beyond anthropology. It is my conviction that ethnographic data and the specific preoccupations that the anthropological tradition of kinship studies has borne have not been sufficiently heard by the neurophysiologists, psychologists, primatologists, and philosophers who have been engaging in that debate. ${ }^{7}$ Part of the reason for that is the difficulty 
that anthropologists have experienced over recent decades in engaging frankly and explicitly in comparison and generalization (see Bloch 2008; Fox \& Gingrich 2002). We are today in a better position to call the attention of other disciplines to how informative and analytically profound are the empirical pickings of our ethnographic tradition (see Pina-Cabral 2010b; 2011).

\section{Naming and personhood}

One's name may be the same as that of another person (a namesake, see Pina-Cabral $2010 a ; 2012$ ) or it may be a teknonym (see Needham 1954), in which case each time the name is used - by us or apropos of us - it co-evokes that other person in a more or less explicit manner, depending on circumstance. There is, however, another kind of affective echo in names, which is related to the fact that our names also bear continued identities because other persons attributed them to us. Our names (a) can evoke our namers, (b) can actualize their intentions as inscribed in the original act of naming, and, finally, (c) convoke a continuity of identity (a co-presence) with the namers. This, of course, is done differently in different socio-cultural environments and depending on each one's personal history. ${ }^{8}$ But it is by no means a specifically Euro-American phenomenon. For example, when a Xavante youth from Mato Grosso state (Brazil) received a name from an older man, the latter lost that name, but the link between the two became profound as a result of the transmission - 'names remain, so to speak, impregnated by the personal characteristics of their bearers' (Lopes da Silva 1986: 81). As a matter of fact, since the early days of anthropology, the puzzles posed by the processes of personal naming have never abandoned our discipline; ${ }^{9}$ we must remember that the debate on personhood in anthropology was kick-started by Mauss's reading of Boas's material on personal naming among the Kwakiutl. ${ }^{10}$

In the course of the reflexive process of self-discovery associated with language learning, the person is literally called into existence by other persons; dividuality, therefore, is formative. Personal naming, which originates in early infancy, ${ }^{11}$ plays a central role in the process of ontogeny. Of course, later on, other relations may also be formative; the dispositions that ground the capacity of humans to learn a language such as alteroception (see Trevarthen 1986) or the propensity to adopt the 'bird's-eye view' (Tomasello 2008) - do not stop operating during the rest of our lives: the process of ontogeny continues till the hour of our death. And, of course, there are no human relations that are destitute of some affective component. Notwithstanding, by adopting the expression the 'core of affects', I mean to stress that some of the early relations of cohabitation create affective dispositions of remarkable long-term fixity; they are, in that personal sense, primordial (Pina-Cabral 2002b).

In the same way as learning how to walk or how to speak takes place differently for each human being, corresponding to a complex evolving process that cannot be repeated (Clark 1997), so also the process of ontogeny of each adult person cannot be separated from her or his particular history. When we meet a named human other - be it in our everyday environment or in a hypothetically very distant ethnographic context - we know that this is a differentiated, unique being, endowed with her or his own dynamic of ontogeny (Carneiro da Cunha 2009 [1978]: 58).

Of course, naming systems vary, and their relation to the singularity of the person depends on culturally specific forms of personal constitution. Nevertheless, it has to be insisted that naming systems and systems of personhood coexist within broad parameters that are common to humankind. Much as we might not be willing today to back 
up Mauss's notion of individuality, the claim he makes in his foundational essay that personal singularity (as we would say today) is largely achieved through the operation of systems of personal naming retains its general validity (Mauss 1985 [1938]: 3).

Following Mauss, most twentieth-century anthropologists were prone to separate selfhood as an 'internal' aspect from socially constituted 'external' personhood (see Douglas 1995). Yet, we are presently engaged in rethinking that form of sociocentric caesurism that fails to see that the constitution of the self as an 'arena of presence and action' (Johnston 2010: 139-41) is something that occurs within ontogeny and is, therefore, closely related to the particular forms of instituting of personhood. As Christina Toren put it,

[A]n anthropological theory of cognition ... cannot be about 'individuals' who are conceptually separate from 'society' and 'culture', whose 'perceptions' can be distinguished from their 'cognitions', whose 'emotions' are neatly separable from their 'rationality'; it has to be about persons who, as loci of the social relations in which they engage, are bound to manifest the biology of cognition as historically located subjects (1999: 115).

The psychological constitution of selves and the social institution of persons in ontogeny are mutually interdependent and they are processes of historical accumulation of personhood. Meyer Fortes's discoveries concerning Tallensi personhood - his insistence that the Tallensi person only achieves full personhood when he dies and when that death crowns a certain type of curriculum (Fortes 1973) - are of general relevance to the extent that they call our attention to the historically constructed nature of personhood and how it is dependent on forms of external propping - such as names, titles, positions, objects, and so on. Relatedness does not depend on the existence of relations between fully formed and identified personal entities, as Monica Konrad (2005), for instance, discovered among the women she interviewed in London. In this sense, present anthropological consensus would lean more towards Tallensi opinions concerning personhood than towards Fortes's own.

\section{What does your name remind you of?}

In order to explore these sets of questions, I decided to work with students from six secondary schools in the two small coastal towns in Bahia (Brazil) where I have been carrying out fieldwork since 2004 - Valença and Una. ${ }^{12}$ I opted for adolescents, since my exploratory interviews had led me to believe that, in contemporary Bahia, adolescence is a centrally important period in people's life concerning matters of personal naming. Until then, Brazilian children encounter their name (or, better still, names) within the small circle of the family and the neighbourhood; the complex relations between the various modes of personal naming and their distinct implications are seldom relevant for the child. Between 11 and 18 years of age, however, adolescents are confronted with increasingly wider contexts of sociality. As they move out of their immediate familial context, their names are re-conceptualized, accompanying and, to a certain extent, preparing a process of growing engagement in the labour market.

From a methodological point of view, the idea of combining participant observation with other, more objectifiable methods of data-gathering has been with anthropologists since the days of Notes and Queries. In fact, I was inspired by the exercises with genealogies that I had engaged upon throughout the late 1980s in northern Portugal (see Pina-Cabral 1991). Later on, in my own work on Macau in the early 199os, I found that secondary school teachers often asked students to make drawings in order to 
encourage them to focus on specific topics of discussion. The analysis of a series of such drawings that a teacher had gathered over the years proved to be highly profitable in examining notions of ethnicity and the way these responded to generational change (see Pina-Cabral 2002a). I found interesting parallels in Christina Toren's work Making sense of history (1990), where she is inspired by cognitive psychology to gather student's drawings so as to judge the way people learn about hierarchy in Fiji.

When preparing for fieldwork in Bahia, I devised a three-layered method that combined asking younger high school students to list the names of the persons who lived in their households; asking the older ones to write short essays discussing what they thought of their names; and asking the mid-level students to make a drawing of the person who gave them their names. In this way, I could gather data concerning personal naming and family belonging from a diversity of angles that combined well with other ethnographic exercises I was undertaking at the same time: interviewing young mothers and nurses at maternity wards concerning name choice; interviewing priests concerning baptism; gathering teachers' family histories; gathering lists of students' names; setting up open-ended discussion groups concerning naming; and so on.

With the enthusiastic support of the teachers, I organized a set of exercises to be carried out in classrooms. The presentation of the project and the gathering of the results were done by myself at first and then by two anthropological assistants. ${ }^{13}$ In this essay we will analyse the responses of students of the seventh year of obligatory schooling, who ranged from 11 to 19 years of age (one of the Una classes was an evening class). The overwhelming majority of the respondents were between 12 and 15 . They were all born locally, residing either in lower-income urban contexts or in peri-urban rural contexts. No cases of refusal were registered, in spite of the fact that students were told that they were free to opt out of the exercise should they so wish; on the whole, they were only too pleased to carry out the task. In most cases, a photo was taken of the students at the end of the class, which always turned out to be a pleasant, lively occasion. We obtained 252 drawings.

The following text (presented here in English translation) was given to the students of the seventh year classes, who were asked to make a drawing on the back of the page.

\section{A drawing concerning my name}

What is a name? - We all have names. Our names are given to us by those who raise us and combine in various ways with theirs.

What does our name remind us of? - Some of us like our name a lot, some like it less, and some do not like it at all. Our name reminds us of something or someone, of some animal, some place, and some situation. Each one of us has a different idea about his or her name: what does your name remind you of?

There are three types of names: PROPER NAME (Cleidiane, Edílson, Pedro, etc.) - which identifies the individual person; SURNAME (Santos, Silva, etc.) - which comes from the father, the mother or the grandparents, indicating the families to which we belong; NICKNAME (Miro, Su, Grandão, etc.) - which may not be the same according to who is calling us: for example, I may have one at school and another one at home.

Please make a drawing of the person who gave you your name.

In the drawing, you may suggest their tastes, their job, where you find yourselves ... 
An overview of the drawings, as well as of the questions the students posed in the classroom, immediately suggests two preliminary considerations. In the first place, we soon became aware that, in spite of the fact that such a sentence was not part of the questionnaire, the question the students felt they were addressing was something more like: 'What does the person who gave you your name remind you of?' (lit. Que lhe lembra a pessoa que lhe deu o nome?). The idea of an association of images to qualify someone was promptly grasped and it carried greater conviction than what they read in the form - on the whole, in fact, they were not attentive readers and started making questions way before finishing reading.

In the second place, 'name' was almost always understood to mean first name (Pedro, António, etc.) and only by extension family name or nickname (apelido). Nevertheless, the fact that we opted for provoking them by making a reference to nicknames in the questionnaire meant that in some classes there were debates about the meaning of nicknames. In consequence, in eight cases, the students made explicit reference to the person who gave them their nickname. Only in three cases, however, and all from the same class, did they fail to make reference to the other names.

The two small towns in Bahia where our study was undertaken are part of the coastal region of northeastern Brazil where the historical influence of African slaves and indigenous inhabitants combined with the settlement of economic migrants from Europe and even from Japan to make up a highly composite population. In many ways, however, the more general aspects of family life conform to those of the landless population of northwestern Iberia from time immemorial (see Pina-Cabral 1986). On the one hand, these are societies where the principle of descent is not operative and where the household is the primary unit of social integration; on the other hand, when there is no landed property, the survival of the household as a unit is strongly dependent on the conjugality of the head couple.

In Bahia, during the first part of people's adult life, conjugal relations are seldom definitive. Claudia Fonseca, in her study of a poor quarter of Porto Alegre, makes a general assessment that would be applicable in broad terms to most of the population of Una and Valença:

[T] here is a prevalence of consensual unions ( $90 \%$ of couples), a high frequency of households are composed by a single mother with her children (roughly 25\%), there is a high rate of conjugal instability and remarriage (...20\% of the women got separated from their husbands during the course of the research), and a high circulation of children ( $50 \%$ of the women with more than 20 years of age had placed at least one child in a substitute home) (2000: 53).

As Susana de Matos Viegas (2007) discovered in her study of a rural settlement in this region, the raising of other people's children by elderly couples (mostly the offspring of daughters and younger sisters) is a structural inevitability as well as a valuable option. Louis Herns Marcelin similarly stresses in his study of Cachoeira that to leave a child in a related household is more in the nature of a right than a favour (1996: 138). As a matter of fact, the household itself is formatively dependent upon relations among people who grew up in vicinages: that is, localized aggregates of households historically related through kinship links (cf. Hammond-Tooke 1963; Webster 2009 [1976]). In constructing people's sense of belonging, intragenerational relations assume far greater centrality than intergenerational ones. In Marcelin's words, '[T]he household ... does not present itself to people's imagination as an absolutely autonomous unit or as 
circumscribed to a delimited space: it is indissociable from the networks of persons and households within which it is defined' (1996: 99).

Again, Cecilia McCallum (2005) has shown in her paper on gender and race in Salvador that central importance is granted to personal independence. This means that, during the first part of people's adult life, when they are attempting to find forms of livelihood that provide them with some security, both men and women are very mobile. As a result, one can identify a process of asynchronicity between the cycle of personal fertility (for men and women) and the cycle of constitution of households, which tends to take place slightly later on in people's lives, when they have already achieved greater economic stability. Contrary to some colleagues (e.g. Blackwood 2005), I find that the concept of matrifocality as developed by Raymond Smith (1996) is a very useful contribution to this debate, since it stresses the fact that these are legitimate and indeed valued forms of familial living. I tend to avoid it, however, since it fails to capture the importance of male participation in family life and, in particular, in the setting up of households by mature couples.

\section{Mothers and fathers}

Let us now consider the 252 drawings with which the students responded to our questionnaire (see Appendix). The person chosen as namer was the mother in 107 cases (in four cases, together with the elder sister or the mother's mother); in 100 cases, it was the father; and in 13 cases, the father/mother couple. In 27 replies they chose other relatives: a grandmother (8); an aunt ( 7 - in one case together with her husband); a cohabiting brother or sister (4); a grandfather (3); an uncle (3); and a cousin (1). In one case it was the godmother (perhaps also aunt). ${ }^{14}$ Whenever it was possible for us to inquire about the relation of these kinsmen to the student, it turned out that they were (i) the child's foster parents ('pais ou mães de criação' - see Matos Viegas 2007: 107-42) and (ii) on the maternal side.

Thus, in 89 per cent of the cases the parents are attributed with the naming (44 per cent mothers, 40 per cent fathers, 5 per cent both together) (Fig. 1). Together, siblings and members of the parent's household of orientation (i.e. grandparents, parental siblings, and co-resident cousins) amount to 10 per cent of the total. What this means is that, even although historically speaking that might not have been the case, the

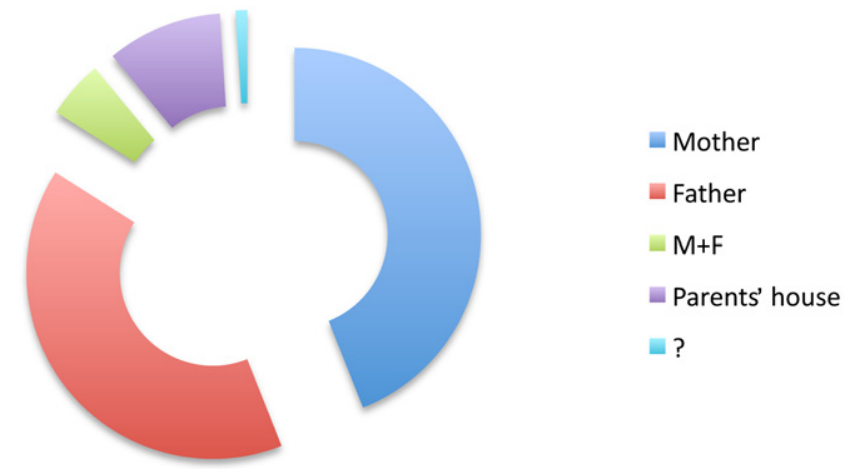

Figure 1. Percentages of relatives who are attributed naming. 
attribution of naming made by the children reinforces either (a) links of filiation or (b) links to the context of cohabitation where they are being raised.

It should be noted, however, that in cases where both parents are present in the drawing, one cannot automatically assume that they are co-resident. For instance, the female student who drew Figure 2 writes in the legend of her drawing 'My father lives away [from town] and my mother also does', thus suggesting that they are separately away. Moreover, the choice of the father as namer does not entitle us to assume either that he is co-resident. One female student explains: 'This is my father. His profession I do not know, as I have not seen him in ten years'. In another, we are emphatically told that the naming father 'lives in London' - he is not travelling (viajando), he is permanently there.

As a matter of fact, it is interesting to observe that some students have chosen to interpret the question 'Who gave you your name?' by celebrating the actual moment when the father visited the Registry Office in order to declare legal paternity, thus literally giving the child his or her name. One male student actually depicts his father as he prepares for the momentous occasion (Fig. 3). In Bahia, this act of declaration of paternity cannot be assumed as automatic under any circumstances (see Pina-Cabral 2005; 2007). Contemplating the scene legitimates the child, even in cases where the father is not co-resident with the mother or is not particularly prestigious himself. In fact, our students emphasized the gift of paternity even in instances where legal paternity remains uncertain - as in a case where the student bears the same first name as his father but not the same surnames.

The moment of public recognition, however, which plays such a central role in the case of fathers, does not have the same relevance when the namers are not fathers. The

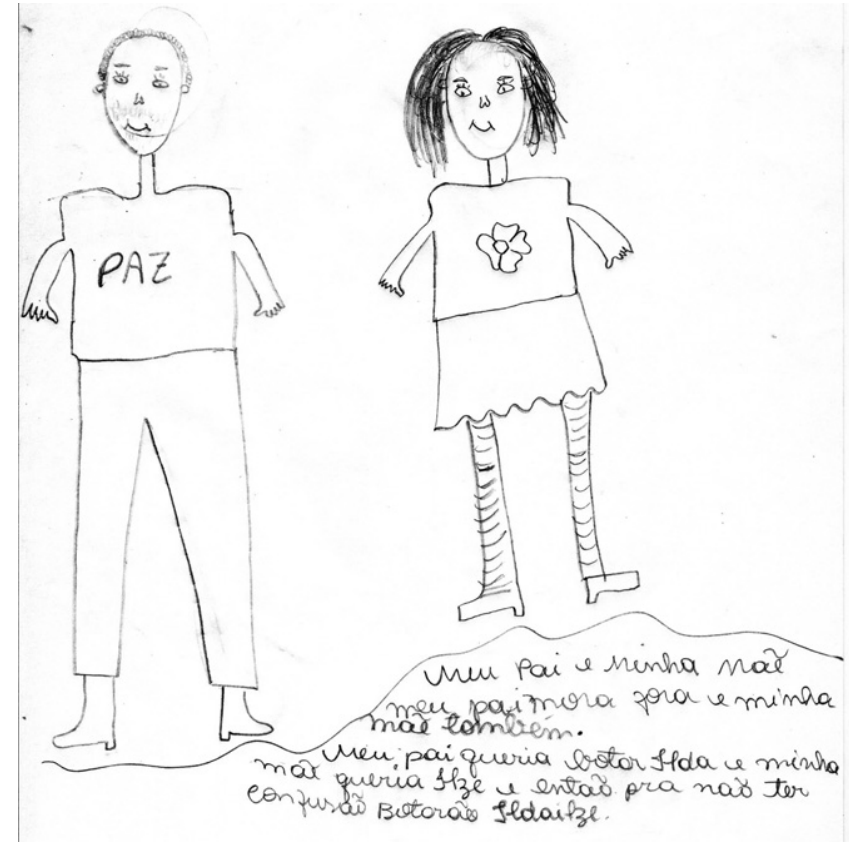

Figure 2. 'My father and my mother. My father lives away and my mother also does. My father wanted to put Ilda and my mother wanted Ilze and so, in order for there to be no confusion, they put Ildailze'. 


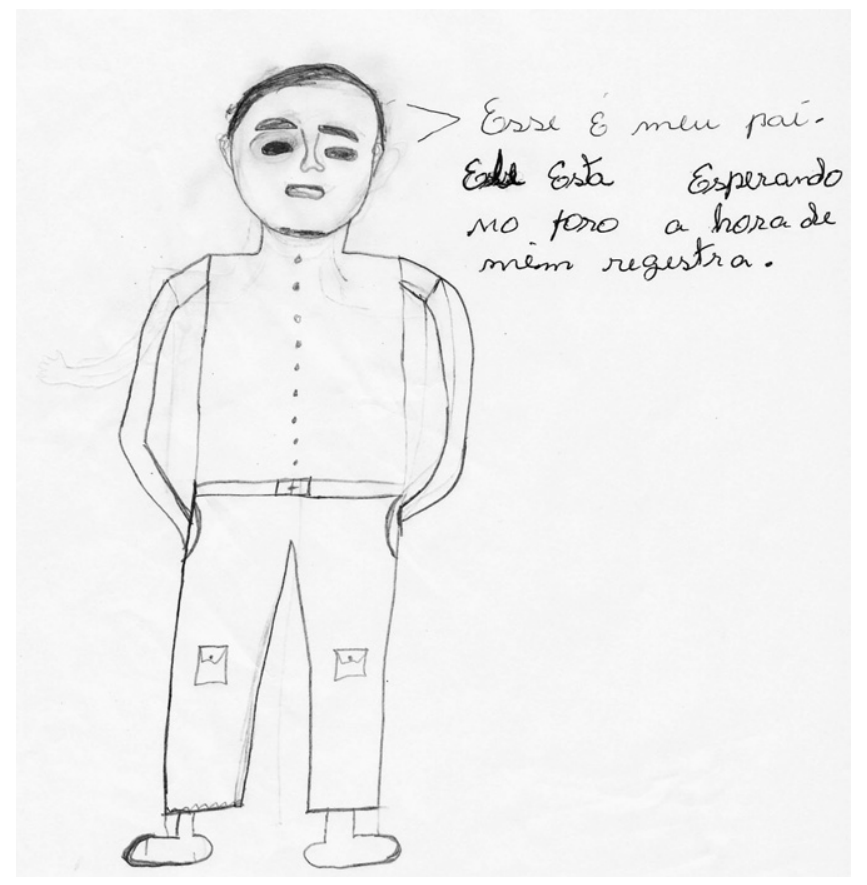

Figure 3. 'This is my father, he is waiting for the opening hour at the administrative building in order to register me'.

drawings reflect this amply. There is a series of drawings where the father is presented in situations in which he is happy for the birth of the child or where he assumes the event publicly: for example, when it is said of a smiling man in a pleasant environment, 'my father is commemorating my birth' or when the child is presented as a kind of phallic extension of the father's body.

Maternity, to the contrary, is not presented as demanding confirmation or public recognition. Again, much the same happens with the twenty-two cases where grandparents or parents' siblings are identified as namers: the relation of fostering (criação, lit. creating, but implying both 'nurturing' and 'raising') is presented as continuous with maternity; as being inevitable, automatic, involving no formal act of declaration. ${ }^{15}$ Grandfathers are presented smiling and grandmothers are systematically depicted either by a kitchen or in continuity with the mother. Uncles are presented in their daily life, whistling happily or laughing 'out of happiness for being alive'. In Figure 4, we may see a smiling aunt watching over her nephew/foster child, who is starting his first professional steps as an apprentice mason. The relaxed attitudes of all uncles, aunts, brothers, sisters, and cousins who feature as namers contrasts with the seriousness of most fathers.

Parental absence is experienced as problematic. In the case of mothers who are absent as migrant labourers, there seems to be no implication of lack of love to accompany physical absence. They are, in fact, presented as glamorous, befitting the image that small-town Brazilians have of the exterior - the desired place of modernity (Fig. 5). In both cases where the father died prematurely, the implication is one of loss 

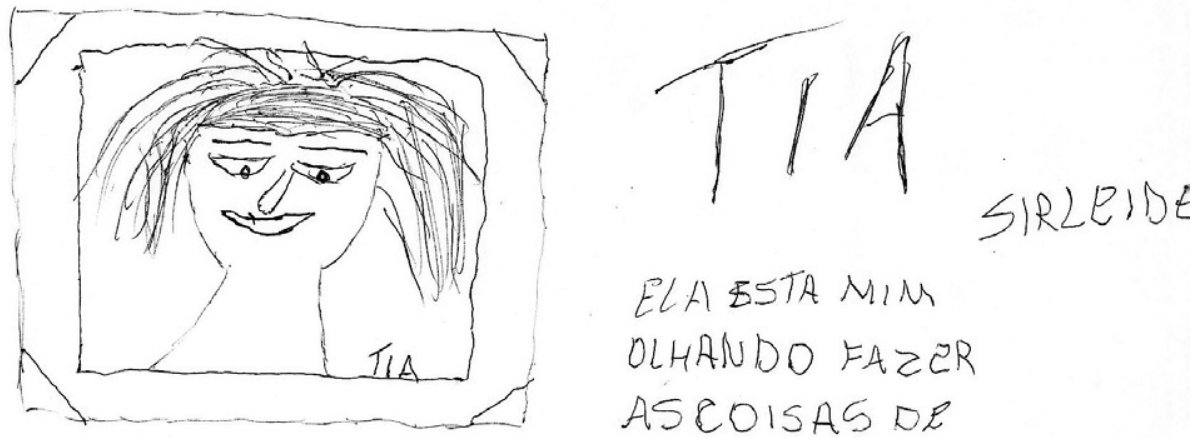

$$
\begin{aligned}
& \text { ELAESTA MIM } \\
& \text { OLHANDO FAZER } \\
& \text { ASROISAS DE } \\
& \text { PEDREIRO, COMA } \\
& \text { MASSA, E REXUNTO }
\end{aligned}
$$

Figure 4. 'Aunt Sirleide. She is looking at me doing the things a mason does with cement and stone'.

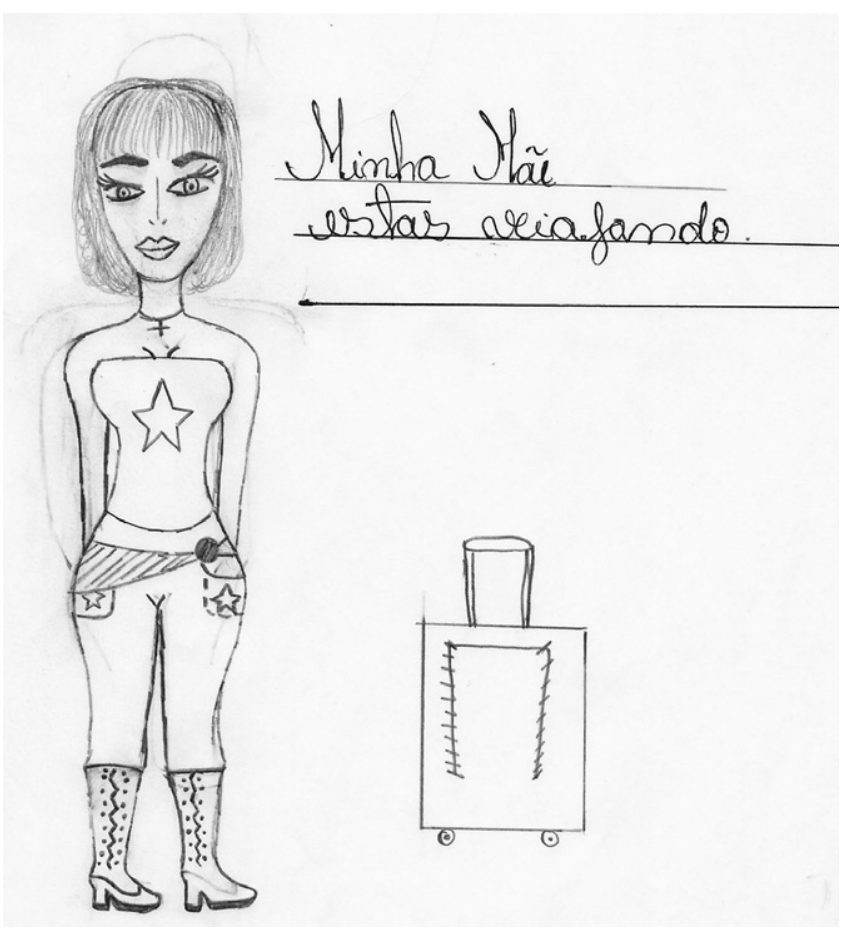

Figure 5. 'My mother, you are travelling'.

and fathers are given wings - they are 'guardian angels', but the inspiration for the imagery draws more on video games than on religion (Fig. 6). The reference to Japanese video games, where fantastic and powerful figures protect infant protagonists, is scattered throughout these drawings. 


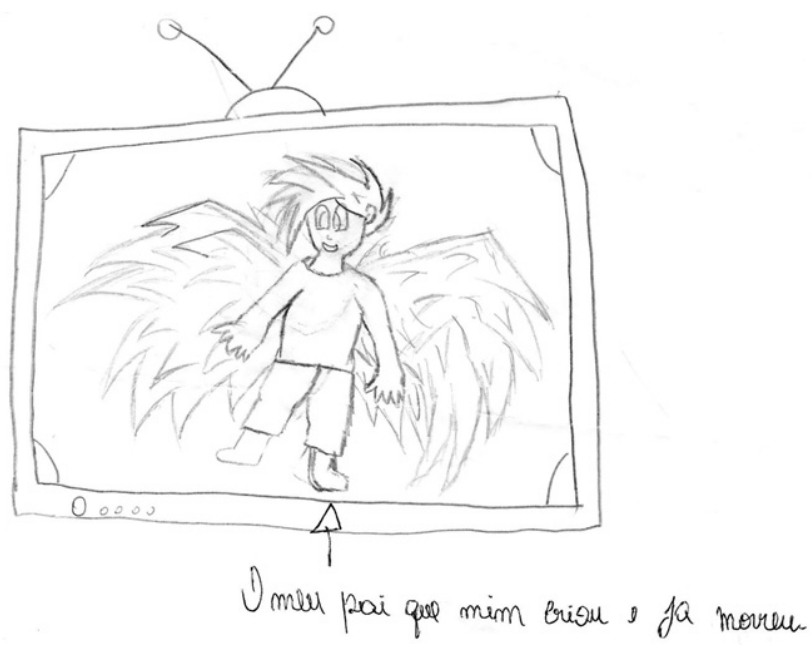

Figure 6. 'My father who has raised me and has died already'.

In one particular case, the feeling of unease demonstrated by a student who was raised by his aunt and his grandfather emerges in a lie/joke that, when the student attempted to correct it, turned into a cry of unhappiness: 'I live (not) in the cemetery, grave number 2005' (Fig. 7). These cases point to the importance of something that is not sufficiently emphasized in normal ethnographic accounts: the role played by contrafactual imagination in the process of identity construction. ${ }^{16}$

Yet another drawing deserves that we should attend to it (Fig. 8). There, once again, the image is patently copied from the style of Japanese comic books. The story we are told, however, is surprising: the boy's father was confronted with his own mother's ghost and got a big fright. The student is telling us about how the familial past imposes itself on the living by taking recourse to what Paul Harris calls pretend-play: '[T] he child temporarily acts out the part of someone other than the self using pretend actions and utterances' (2000: 30). Once again, the video game imagery is not specific; students use it to infuse perfectly domestic situations with power. What must be kept in mind, however, is that these imaginary detours do not dispense with strong affective investments: '[C]hildren might be aware that their absent companion or the monster waiting in the dark are purely imaginary even as they react with distress or fear' (Harris 2000: 60).

In the thirteen drawings that attribute naming to both parents, we often come across emphatic affirmations of love between them. In one of these, for instance, the sentence 'True Love' is written between both parents and the legend reads: 'This drawing reminds me of [lit. remembers me] my father and my mother in a super-tranquil spot, the two of them alone'. We are not entitled to read this declaration of self-absence ('the two of them alone') as one of exclusion of ego, since the tone of the drawing is explicitly affectionate. We must, therefore, read it as a declaration of the immanence of ego in the love relation of the parents. She is, in fact, co-present by implication.

In this case, this 17-year-old female student expresses her own romantic desires of love. We can observe here a slide in identity between namer and named through a joint investment in aspects of the world that is characteristic of many of these drawings. 


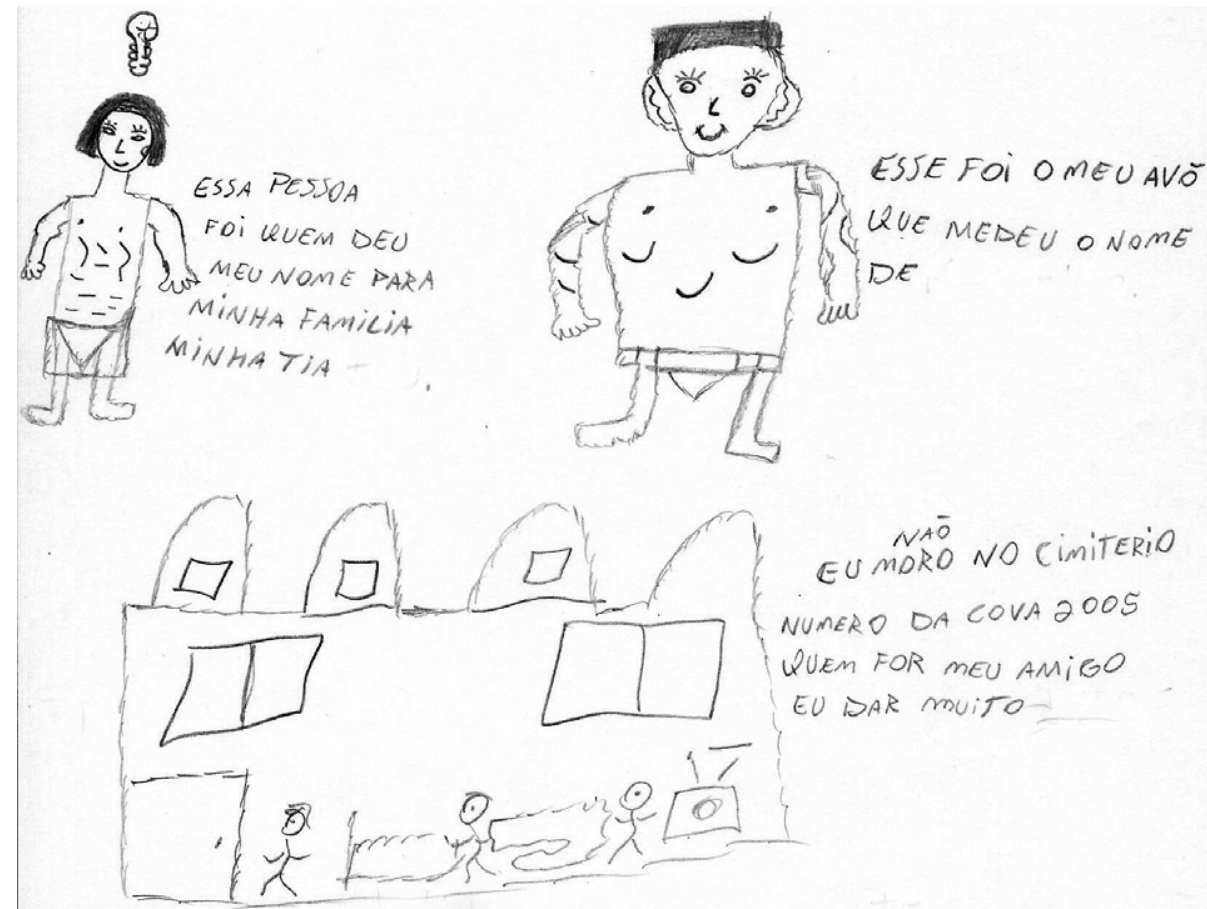

Figure 7. 'This person gave my name to my family, Aunt Tatu. That one is my grandfather who gave me the name Valdemiro. I live (not) in the cemetery, grave number 2005. To whoever is my friend, I will give much ... [erased]'.

While the aspects emphasized by the drawing are supposed to qualify the namer, they would better qualify the aspirations and desires of the named. We are faced with a kind of surrogation of desire where both persons are invested with each other's qualities and interests: continued identity is experienced in the manner of surrogation (Pina-Cabral 2003: 148). In its broadest sense, the word 'surrogation' means 'to assume the role of another'. It has been used in literary theory to describe Hamlet's relation to his father, for example (Loftis 2009: 85), while elsewhere it designates the practices of endocannibalism that once characterized some Amerindian societies. In my use of the expression, I do not retain the notion of illusion or phantasmagoria, however, since I want to stress here the constitutive, palpable, objectivized aspect of continued identity (see Roach 1996).

It has to be stressed, however, that the world inhabited by the son or daughter is not the same world that the parent inhabits; the conditions that mould the parent diverge from those that mould the child. The occurrence of surrogation, therefore, cannot be taken to imply confusion of personhood. Nor does it imply intrafamiliar mimesis, as it is projected both from named to namer and vice versa. To the contrary, it involves a disposition akin to the shared intentionality of early ontogeny. I am reminded here of Michael Tomasello's comment concerning collaborative activities of the domestic type: 'multiple individuals pursuing a joint goal - and all knowing together that they are doing so - with interrelated, complementary roles. This kind of collaboration requires 


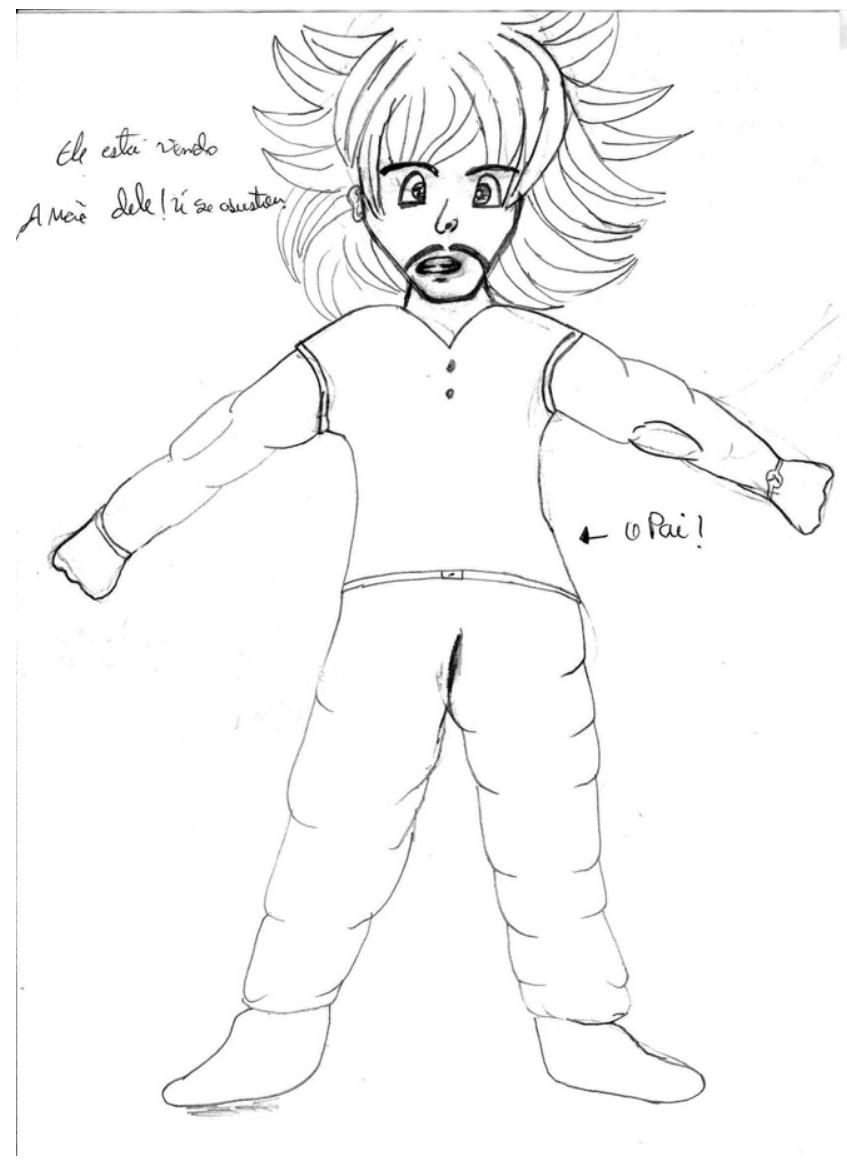

Figure 8. 'He is seeing his mother, and he got frightened'.

... skills and motivations for shared intentionality, including as the basic socialcognitive prerequisite, recursive mindreading' (2008: 173).

\section{Continued identity}

Among our drawings, there are 122 images of mothers, ${ }^{17}$ of which 44 include no particular iconic association apart from the smiling faces and the pleasant tone. Out of the remaining 78 images of mothers, around 40 per cent (32) emphasize the importance of the role of provider by reference to the kitchen (11) or to the mother's profession (21). Twelve maternal images are associated with activities of leisure that strongly appeal to these adolescents and that correspond to the style of continued identity by surrogation referred to above. In Figure 9, for example, the drawing both includes and reproduces the mother's painting. Another such drawing achieves the same effect by recourse to photography.

In six cases, there are explicit references to the mother's involvement in religious activities and, interestingly, they do not convey a sense of happiness, as if suggesting that the mother's involvement with religion (most likely in a neo-Pentecostal church) 


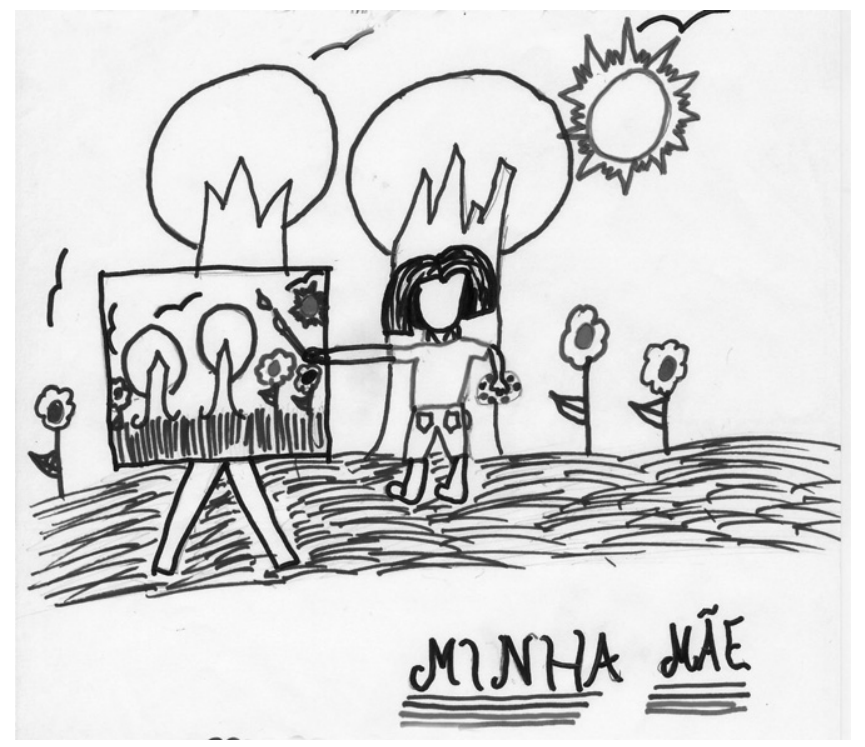

Figure 9. 'My mother'.

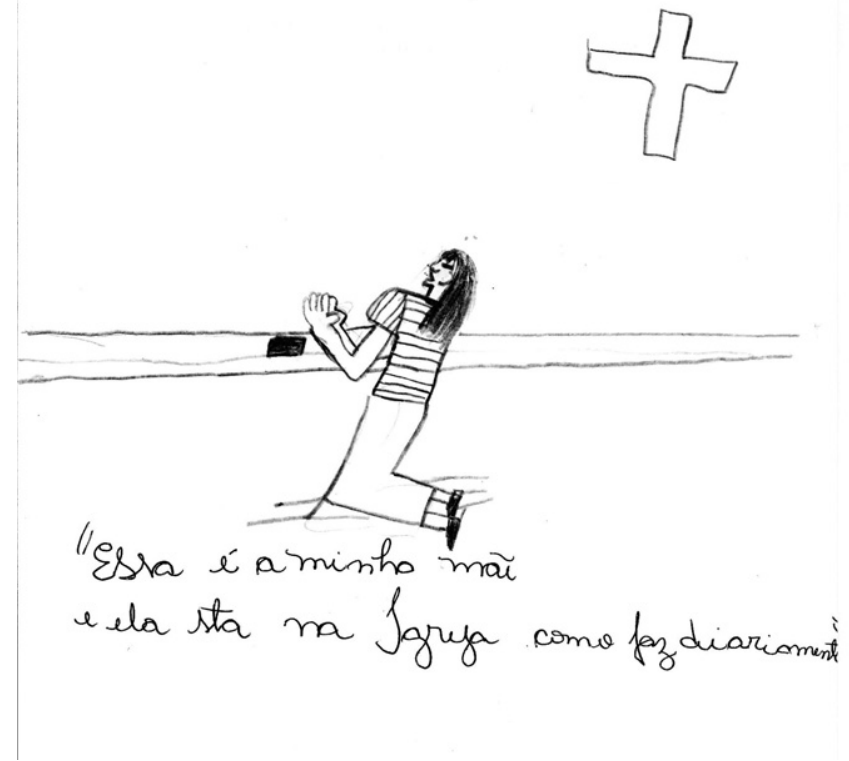

Figure 10. 'This is my mother and she is in church as she does daily'.

distances her. In one case (Fig. 10), the image of the mother is even anguished and the legend leaves a hint of criticism: 'This is my mother and she is in church as she does daily'.

Finally, there is a large group of twenty-eight drawings in which the mothers are associated with flowering landscapes, flowering gardens, sunny beaches, or simply 
represented by flowers. The same is the case with all of the ten drawings of grandmothers. A good number of the further twelve images that refer to maternal leisure activities should also be included here: they all instantiate an imagery of nourishing 'Nature' stereotyped in trees, hills, and flowers. Flowers are stamped in a large number of pieces of clothing of mothers, grandfathers, grandmothers, and aunts.

A similar trope is that of the stylized (red) heart. These hearts may occupy the whole page (in the same way as when a mother is represented by a flower) or they may be drawn onto people's clothing. In the case of the stylized heart, we can safely argue that it is an emoticon; a standardized mode of signifying 'love'. To the contrary, in the earlier case of the flowers and the landscape, we are halfway between an emoticon and a reference to a desired lifestyle. In both cases, however, what is being emphasized is that the relation the drawing evokes is situated on the core of affects - quite in the same way as when I add $\odot$ to a sentence, thus signalling a jocular mood. Nevertheless, as Luigi Anolli, Rita Ciceri, and Guiseppe Riva have commented, 'while emoticons are defined as vehicles to express emotion - hence "emotional icon" - their actual function hinges on the definition of the word emotion' (2002: 207). Different users attribute different implications to the fact that an emotion is at stake. In fact, according to these authors, this typically differs between men and women.

As a matter of fact, in these drawings, the nature of the gender of the person evoked also affects the meaning and implications attributed to the drawing. This is particularly visible in the way the sun is used to instil the picture with an emotionally positive tone. The associations are strongly feminine, even though the word in Portuguese is masculine. In fact, the moon appears only in one drawing, and that is a visibly unhappy representation of a father who is a neo-Pentecostal minister (Fig. 11). Twenty-one of the twenty-eight

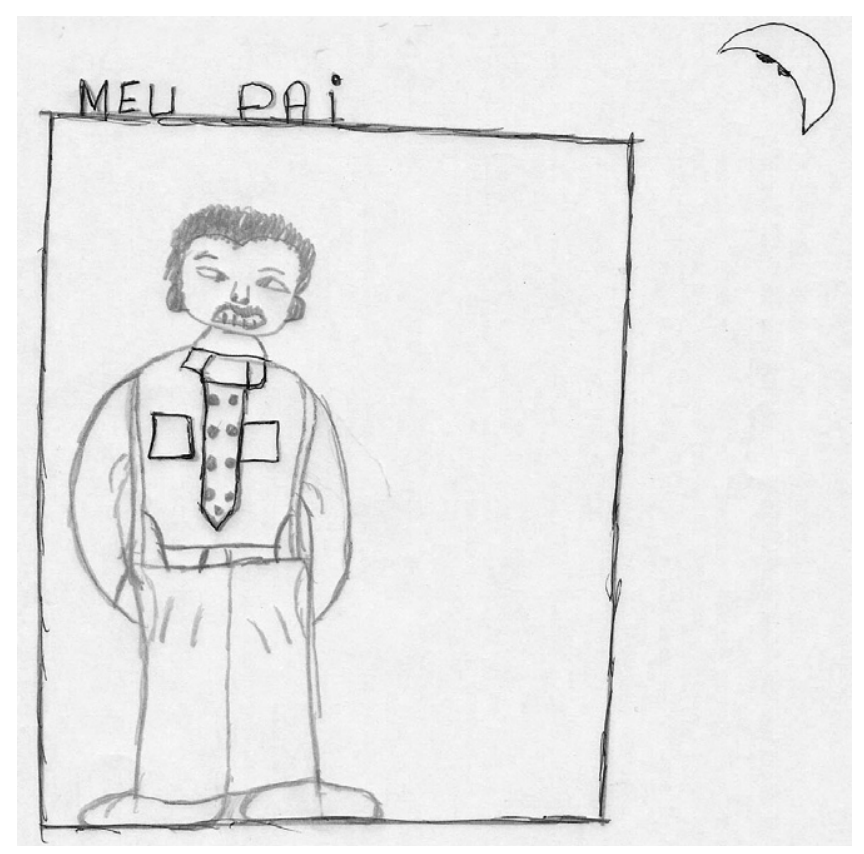

Figure 11. 'This is my father; he is on his way to church'. 
instances of suns are associated with mothers or grandmothers. In one particular drawing, the student says of her mother: 'She is my sun, because she illuminates my life, every day and every night'. The incongruity of the mother being a sun also at night helps one to understand what is being communicated: she is my source of nourishment, joy, safety, and well-being. Eleven of the twenty-eight representations humanize the sun by attributing facial features to it. Again, since there is no reference in the local context to any mythical personification of the sun, the attribution of human features does not suggest that the sun is seen as a person; rather, it seems to radiate humanity.

The emphasis on 'love' that is widespread throughout these drawings (and the implicit association between love, well-being, and joy) is characteristic of the local Bahian cultural style. It plays the same role here as it does in the soap operas that everyone eagerly watches each evening (see Almeida 2003). This hedonistic tone is also strongly present in the associations made by many drawings between mothers and pleasant leisure activities, but it is especially noticeable in the case of fathers.

There are 118 drawings where the father is present (e.g. Fig. 12) ${ }^{18}$ A quarter of these (28) present the father without any particular association or associated with specific events like the Registry Office scene or the father who sees the ghost of the grandmother. A third of the drawings (39) refer to the father's profession, both presenting him as a provider and signalling the environment with which he is associated (a garage, a shop, a truck, etc.). Frequently, however, they further associate the father with desired consumption styles or with locally prestigious activities. In four cases there is a reference to religion, but the large majority of cases are associated with the world of the Internet and electronics, with sports, and with the beach (Fig. 13). Aside from the profession, however, the most common reference by far is to (a) football (11) and (b) motorized transports (cars, boats, motorbikes

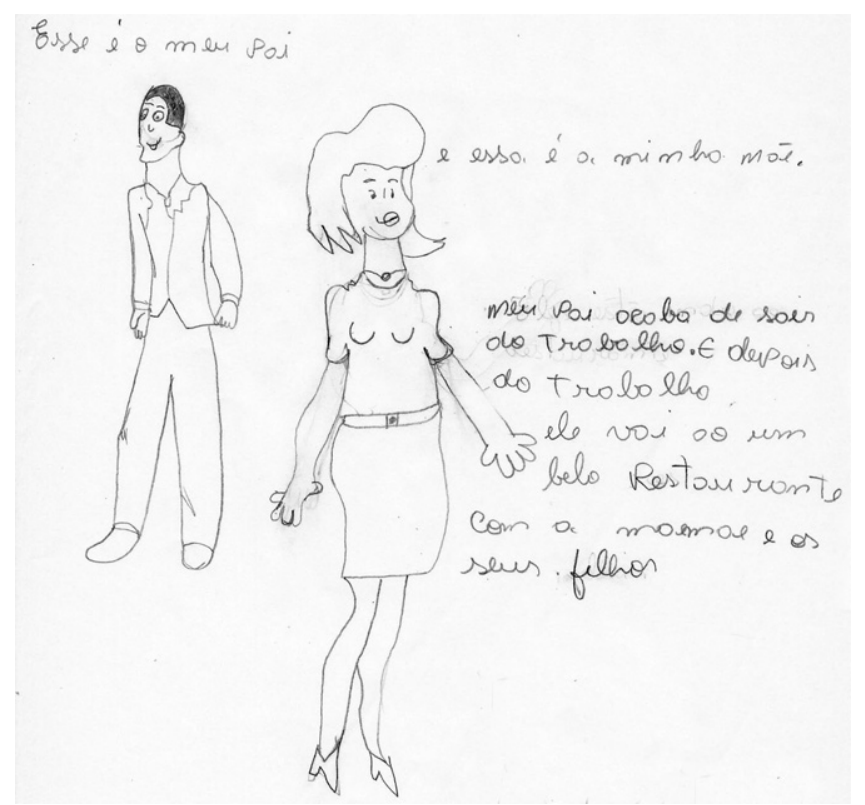

Figure 12. 'My father has just left work ... he is going to a beautiful restaurant with mummy and his children'. 


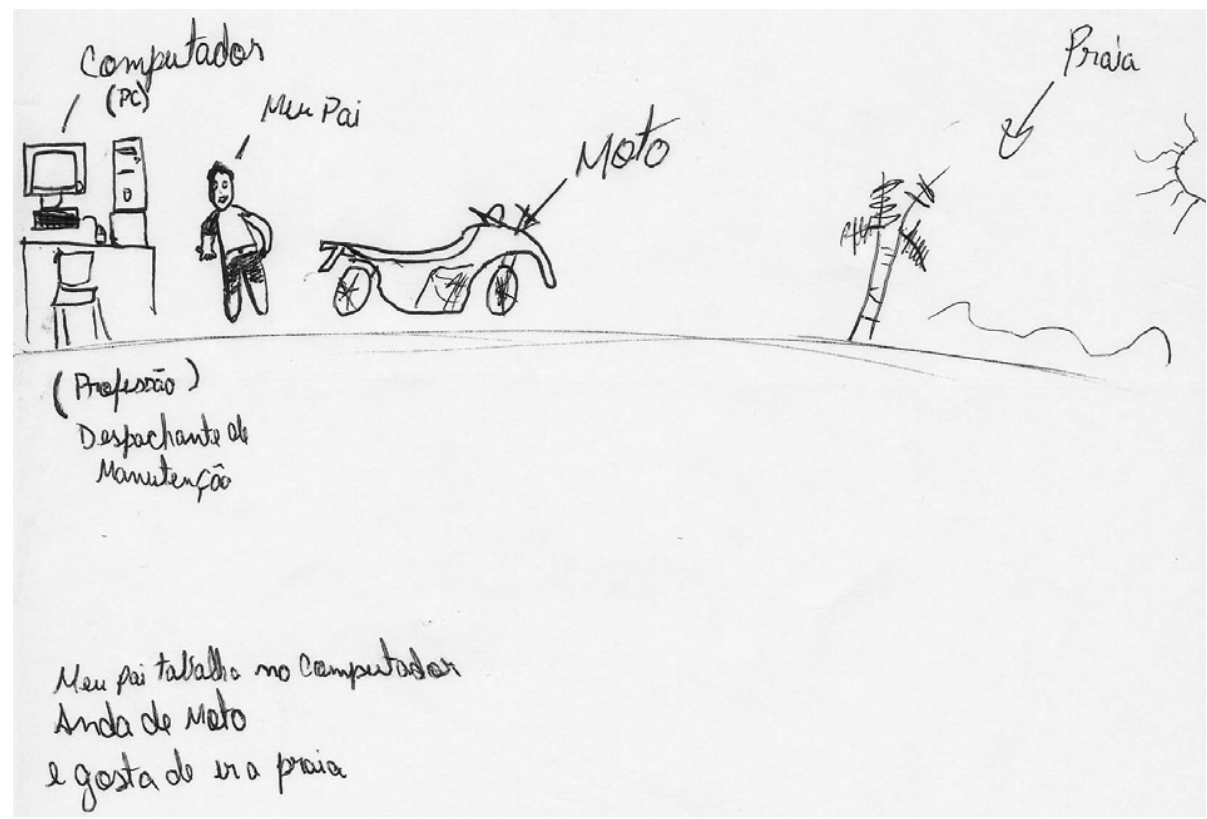

Figure 13. 'My father works in [sic] the computer, drives a motorbike and likes to go to the beach'.

-17 cases) or a combination of both. There are also musician fathers (2), fathers who love gardens or are dedicated environmentalists (6), fathers who practise boxing, and fathers who breed birds. In six cases there are explicit references to fashion, expensive brands, or explicitly youthful forms of dressing.

All of these cases, as well as the majority of presentations of mothers and grandmothers, are clear instances of continued identity by surrogation. Once again it is worth stressing that it is not a matter of mimesis or imitation. In fact, the likelihood that the tastes these children impute to their parents actually correspond to those of the parents is not high. For example, a girl who presents herself as a small version of her darling godmother visibly copies the style from a comic book - a style more suitable to the girl than to the godmother (Fig. 14). There is no mimesis there, neither in one direction nor the other, not even of the two vis-à-vis the comic book characters that the style implies. We are very far from any notion of socialization by 'acquisition'.

Continued identity is a form of co-presence, an emotionally relevant investment that institutes continuity between persons - the process is more akin to pretend-play, in the sense of entering the emotional world of another, than to any form of mimetic representation. It goes both ways - as is evident in the case where the father is presented on an envelope 'in the form of a child'. Similarly, in Figure 15, a football chart is reproduced. Here, the ambiguity of identity is actually theorized:

My father gave me my name [Bismarques] in homage to a great football player, an athlete of Brazilian clubs who also plays in the national team. My father's profession is registered farm hand and he is also a manager of farms. My parents want me to be a footballer. I like playing football, so I aim to become an athlete one day in some Brazilian club, but it has to be a professional one; this field represents my father, because he plays football and it also represents me (my emphasis). 


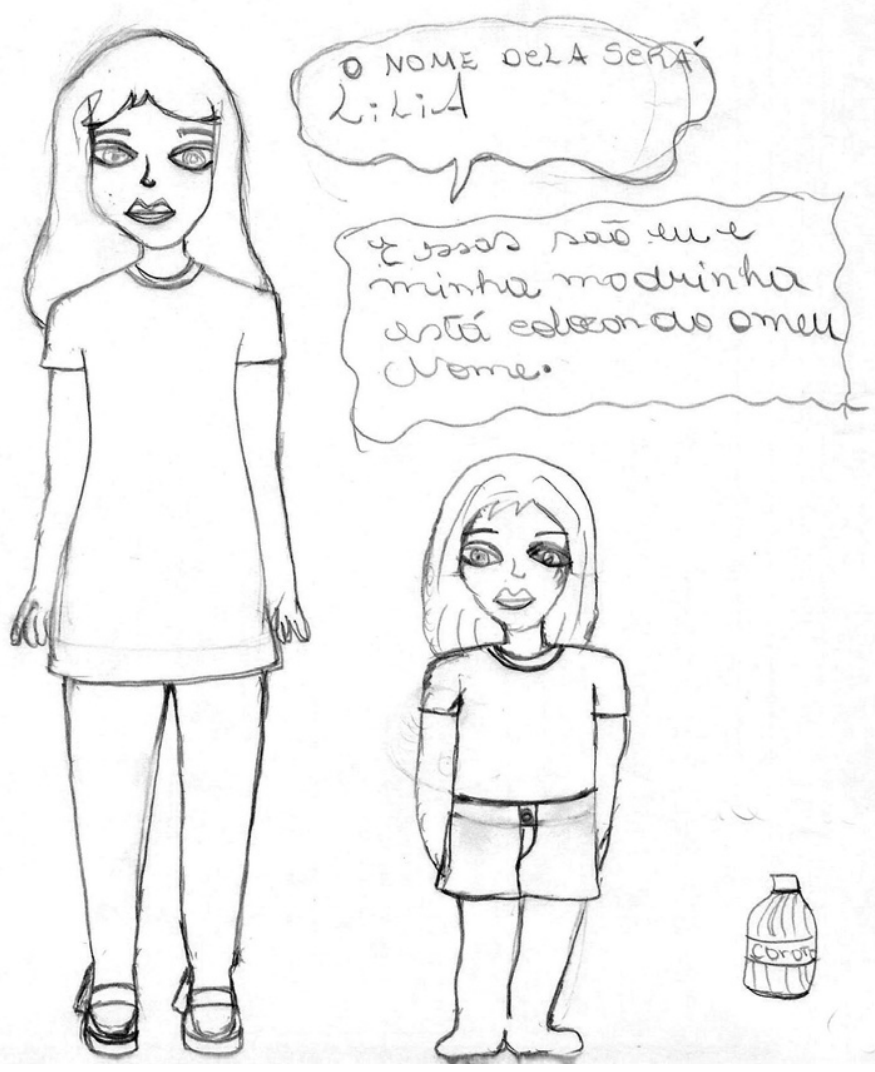

Figure 14. 'Her name will be Lilia'. 'These are me and my godmother, she is placing my name'.

This mode of surrogation between father and son is very common and it works in both directions. An older evening student from Una, whom we asked to write about his name, replied:

I am called Sílvio Gonçalves and I like my name very much as I find it very beautiful and also because it is not very common. I think it matches me, and that is why I like it. I have a son who is called Gleidson. I personally chose that name for him because I thought it was beautiful. I hope he likes it just as much as I do. SILVIO GONÇALVES AND GLEIDSON GONÇALVES ONE SINGLE PERSON (his own emphasis).

I must stress the way in which, in these drawings, the process of attachment and differentiation of the namers is carried out in continuity with the interests and tastes that identify the named. A continued identity is thus reinforced in the way in which one of the pair is invested with the marks of the other's world. Without there being any confusion between the two, they are both mutually invested in a common world through a process of creative emotional imagination. This continued identity is the shape in which the world reflects back upon the namer the investment made by the named in his or her own constitution as a social being. Therefore, as they imaginatively present these relations, the students who answered our questionnaire were working 


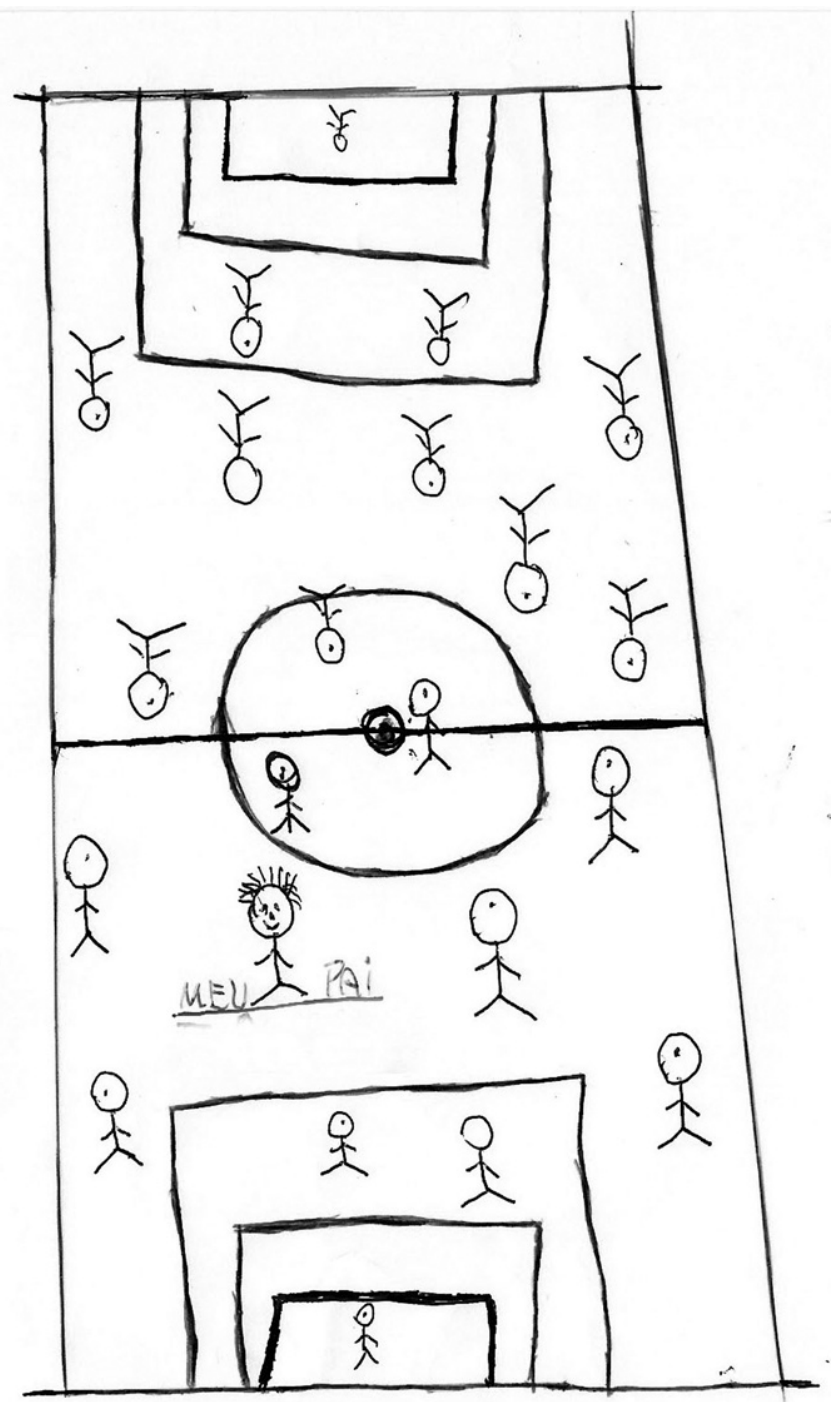

Figure 15. Bismarques.

upon the core of their affects: they reified and elaborated upon the more primordial aspects of their constitution as persons.

These identifications, however, are sometimes made in a minor key, as it were, especially in the five instances where students chose to associate their fathers with drink or tobacco. When we are presented with a bottle of the rum-based drink Cocote and a cigarette packet to stand for the father, there might still be a chance of some emulation, but when we see a picture of a beer-bellied man in the road clutching a bottle and with a foolish grin on his face (Fig. 16), a sense of despisal begins to emerge. In the case of one caption, however, we must read the association with alcohol in a positive light, as an explicit and ferocious attack on neo-Pentecostalism: 'Isopor is my shepherd and beer 


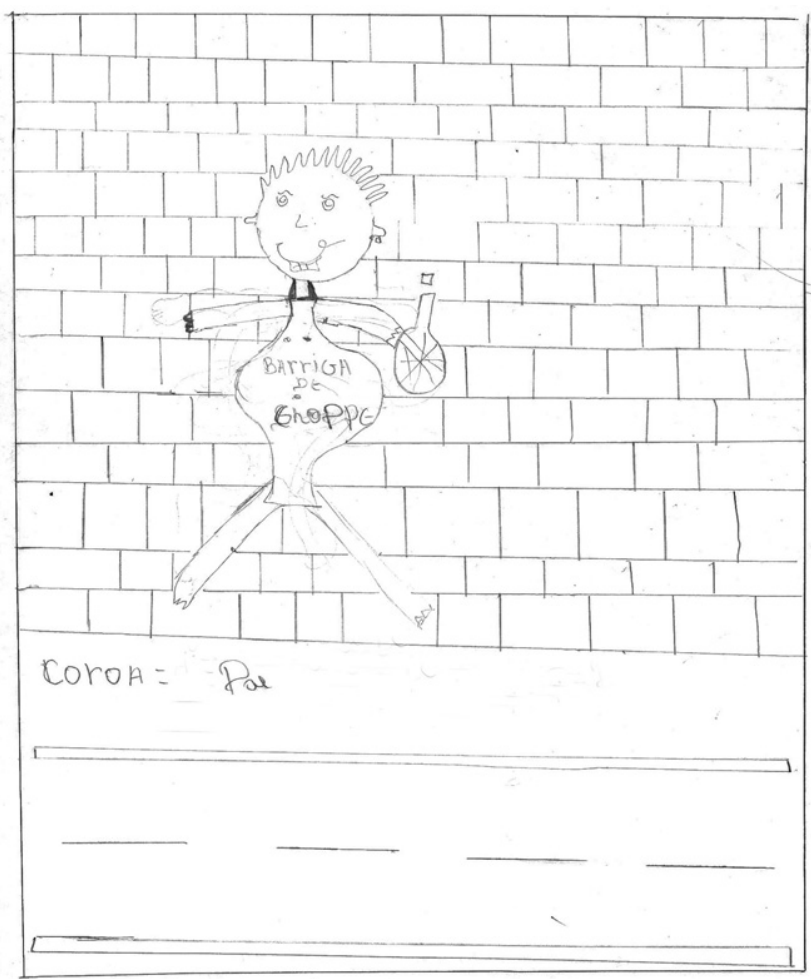

Figure 16. 'Beer belly. Old man = Father'.

I shall not lack'. In this region, where religious attendance is on the increase, everyone would be conscious of the political implications of applying the words of the favourite psalm to the polystyrene boxes where beer is kept cool during the long evenings of music and dance that everyone so enjoys locally.

The only explicit case of criticism in the whole set of drawings is benevolent: a boy depicts his father with a fashionably fitted Nike cap and comments, 'My father unfortunately is a smoker'. The students who claim their fathers only like money or the one whose smiling self receives a 50 Reais note from a rather distressed father (Fig. 17) may regret their father's unwillingness to part with money, but they are celebrating in this way the gift of sustenance: 'Money reminds me of my father, since he provides for all the material goods that I require'. And, finally, there is even a sad but kind depiction by a girl of a rather handsome father who is said to be unemployed.

The gender of the named is also an aspect where we witness the workings of continued identity by surrogation: 60 per cent of the students indicate as namer someone of their own gender ( 57 per cent for males, 62 per cent for females - that there are more women than men among the namers reflects the matrifocal propensity of local society: PinaCabral 2007). There is, however, a greater propensity for girls to attribute the naming to a couple ( 7 per cent versus 5 per cent in the case of boys), which is a sign of the greater emphasis on romantic love among young women than among young men.

Finally, the genderizing of the namers is omnipresent in these depictions. People are often represented by objects that fit adequately their gender stereotype: flowers and fruit 

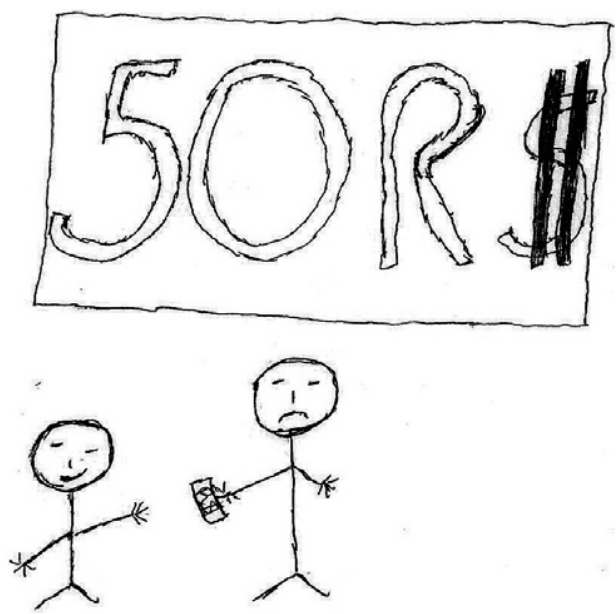

Dinheiro lembra meu pai, poin, rodas an coisan mareriais que en Preciso ele me consegue.

Figure 17. 'Money reminds me of my father, since he provides for all the material goods that I require'.

in the case of women; cars and motorbikes in the case of men. The two instances where this is not the case - a mother represented by a boat and a father represented by flowers - are, once again, instances of surrogative metonymy: instead of depicting their parents by reference to the parents' gender, they opt for reflecting their own gender tastes. Indeed, our material fully corroborates Christina Toren's observation that 'for even the youngest children [in her sample], experience seems to be gender specific' (1990: 218). When names, somehow, lead to gender confusion, this is noted. The child might not reject the name he or she has been given, but will need to invest more work in the name, treating it as a challenge. Figure 18 depicts Brendo and his father arriving by bus in Rio de Janeiro and going to lunch. The father is clearly portrayed as masculine, but Brendo is not - note the long hair. The ambiguity, however, is resolved by means of a label where it becomes clear that, although the name might be ambivalent (as it is a version of the feminine Brenda), the 13 year old is unambiguously male ('Brendo masculino 13').

Gender binarism is very intense. Only in one or two less elaborate drawings is it hard to identify at first glance the gender of the named. As a matter of fact, a whole imagery of gender polarization in terms of the human body emerges: when namers are not presented in professional contexts that immediately differentiate them (mothers are nurses, cleaners, teachers, shop-keepers; fathers are drivers, construction workers, painters, computer technicians, policemen, civil servants), the differentiation is overstressed by exaggerating the standard distinguishing features: long hair and breasts for women versus chest and arm muscles, bald heads, and moustaches for men.

The manner of surrogation that we have identified in the drawings of these Brazilian children denies neither personal singularity nor personal plurality. As Marilyn Strathern warned us long ago, 'Melanesian persons are as dividually as they are individually conceived' (1988:13). We similarly observe here a mode of self-constitution where dividual 


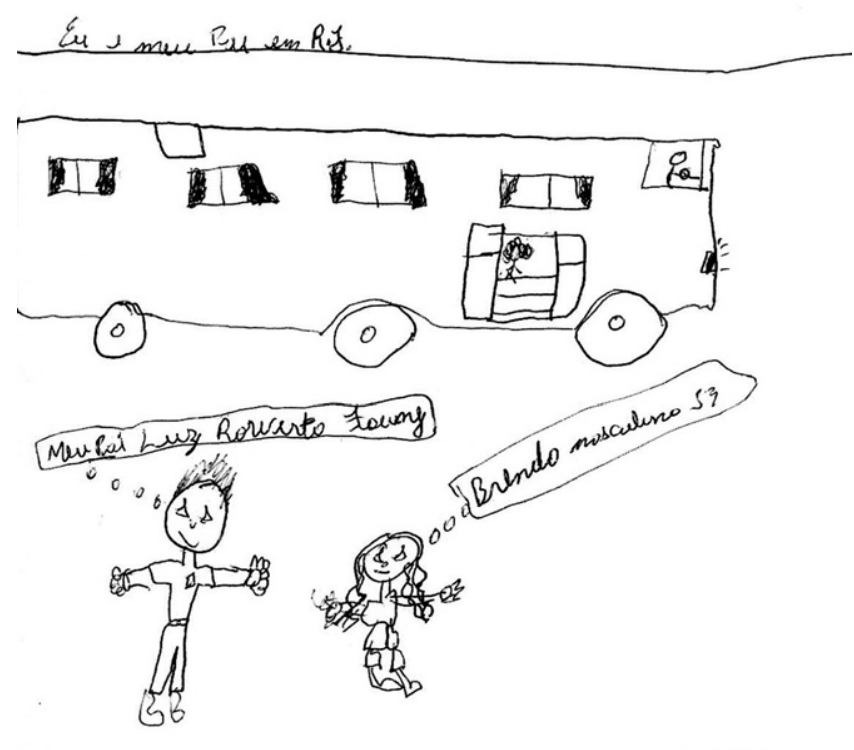

Figure 18. Brendo and his father arrive in Rio de Janeiro.

mutuality relates dynamically with face-to-face confrontation; attachment confronts differentiation in historically layered processes of ontogeny; singularity and plurality constantly resolve into each other by complex shifts in perspectival positioning before the world.

The fascinated enjoyment the adolescents evinced in making these drawings shows that they felt compelled to 'work upon the core of their affects'. There was a visible element of play in the manipulation of one's name that I so often encountered during my research on naming in Bahia. Narrating one's name is a form of constructive manipulation of oneself. We asked 101 older students in Una as to whether they 'liked' their name and why. Of these, 75 per cent explained why they did and 5 per cent expounded on how they had come to like their names. The 17 per cent who claimed not to like their name nevertheless were precisely those who invested more in actively reinterpreting their name. We witness here the same paradox that Donald Winnicott noted in the case of all transitional objects: ' $\mathrm{T}]$ he baby creates the object, but the object was there waiting to be created and waiting to become a cathected object' (i.e. an object upon which emotional energy is invested; 1971: 89). Thus, the name works both as a mediator between self and other and as a mediator between person and world. By being out there, as it were, indestructibly, it allows for manipulation to occur.

\section{Conclusion}

In Bahia, we have seen, the process through which a person acquires a name promotes continued identities. These, however, must not be seen as mental schemata or processes of a cognitive nature; rather, they are perspectives before the world, they are who we are. Later on in life, other relations (such as conjugality, master-disciple, or friendship of various kinds) can also enter one's core of affects and, of course, the process of social construction by means of mutuality is far wider: it includes belongings of various kinds - religious, national, ethnic, and so on. 
Their personal name inserts these Bahian adolescents into contexts of sociality that imply relational choices, transporting rights, and obligations. Naming and family belonging are intertwined. The possibility of each one's existence is grounded in an ontology of the namer. A student insists: 'This is my father. His name is Mário but I call him Super Mario because if it were not for him I would not have been born, I would not have gone to school and I would not be here now' (my emphasis). ${ }^{19}$ The inevitability of the anterior existence of the namer, however, presents us with an interesting ethical question. In the words of Lévi-Strauss in The savage mind, there is a 'moral passivity, which projects upon the child an image created by others' (1966:180). We may ask ourselves, then: since it obliges the child, to what extent is this process of naming a kind of oppression?

This question, however, only makes sense if we assume that persons are individuals, that social participation is optional, in the sense of being subsequent upon personal constitution, and that what the child is taking on is a representation, an image (see Pina-Cabral 2010a). In fact, this impression that the person as a determinable entity pre-exists the characteristics that constitute it as a person is no more than a mirage. Naming, baptizing, circumcising, genderizing, are not violations of a person - or, rather, yes they are violence, but constitutive violence, because no one would exist without them. The person is not betrayed by the founding act of naming- he or she is constituted by it in co-presence. Alhough, later on in life, the child may come to reject the mutualities that gave rise to his or her dividual existence, in Bahia at least this is very seldom the case. These formative surrogations are normally assumed in a register of happiness, joy, and 'love' - in a major key, as it were. That is the message intended by all those flowers, hearts, and suns; the emoticons that fill these drawings. Even the 17 per cent of people who claimed not to like their name did not contemplate the possibility of changing it. In the course of life, the person alters the core of affects, complexifies it, unfolds it, and extends it; but very seldom does she obliterate her primordial mutualities.

Now, here, as in all human action, irreversibility coexists with unpredictability as fundamental characteristics of the human condition (Arendt 1958: 233; see Pina-Cabral $2010 b$ ). Persons are dividuals but their existence is a function of their personal history, not an instantiation of some general existence ('society', 'culture', 'humanity', 'civilization'). Derrida argues that, when we treat a newborn child as part of a 'we',

this communal dissymmetry remains at once extraordinary and, precisely, most common. It is the origin of the common, happening each time we address someone, each time we call them while supposing, that is to say while imposing a 'we,' and thus while inscribing the other person into this situation of an at once spectral and patriarchic nursling (1995: 41-2, original emphasis; see also Pina-Cabral 2010c).

Ontogeny is, in this socio-cultural sense, a negotiation of domination. ${ }^{20}$

The attribution of a name is never simply an automatic or mechanical occurrence. The flame of identity that shines in the eye of the one who responds to his name (or, alternatively, the timidity or fury of the one who refuses to do so) shows that our identity is constructed upon the affective binds of which, as dividual persons, we are a repository and that we can never forget or wipe out but only displace or relocate. ${ }^{21}$ Affects are the attitudes that connect our existence to particular aspects of the world. Those affects that are associated with our mutualities of being are primordial to the extent that, once instituted, they can no longer be laid aside: in future, we will always work upon that core of affects. Even when displaced, the history of that displacement will remain a central part of our ontogeny. 
98 Joẽo de Pina-Cabral

\section{APPENDIX}

Relation of stated namer to respondent

\begin{tabular}{lr} 
Relation & No. \\
\hline$M$ & 103 \\
F & 100 \\
M/F & 13 \\
M/MM & 2 \\
M/Z & 2 \\
B/Z & 4 \\
MM & 8 \\
MF & 3 \\
MZ & 6 \\
MB & 2 \\
MZD & 1 \\
Godmother & 1 \\
MZ/MZH & 1 \\
Colleagues (nickname) & 3 \\
? & 3 \\
Total & 252 \\
\hline
\end{tabular}

Note. Sometimes the drawing may include more figures than just the namer. This list, however, refers only to those explicitly stated as namers. The three unknowns correspond to utterly indecipherable drawings.

\section{NOTES}

The research for this article was made possible by the Foundation for Science and Technology, Portugal (FEDER, POCI/ANT/61198/2004 and PTDC/CS-ANT/102957/2008) and the Institute of Social Sciences of the University of Lisbon. I am grateful to Susana de Matos Viegas, Joana Oliveira, Omar Ribeiro Thomaz, Ana Lúcia Schritzmeyer, Vanda Aparecida da Silva, and Christina Toren for their help. I was welcomed with immense generosity in Bahia, most especially by Araken and Euzedir Vaz Galvão, Edilson Teixeira, and Cecilia McCallum.

${ }^{1}$ Concerning dividuality, see the debates in JRAI 16: 2 (Barker 2010; Errington \& Gewertz 2010; Knauft 2010; Mosko 2010a; 2010b; Robbins 2010) or Konrad (2005: 44-6).

${ }^{2}$ See also Alessandro Duranti's rather useful formulation of a broad notion of intersubjectivity inspired in Husserl's work (Duranti 2008: 491).

${ }^{3}$ In Judith Butler's words: '[W]e are, from the start, interrupted by alterity and not fully recoverable to ourselves' (2001: 35).

${ }^{4}$ See the interesting way in which Monica Konrad interprets anthropologically Lacanian ideas concerning the father as a third person (2005: 48).

${ }^{5}$ Emmanuel Levinas has an inspired formulation for this notion when he claims that 'beings exist in relation, of course, but approached from their own angle and not from the angle of the totality' ('les êtres existent en relation certes, mais à partir de soi et non pas à partir de la totalité') (1971: 8).

${ }^{6}$ I am influenced here by Anthony Chemero's notion of radically embodied cognition (2009) and Andy Clark's argument that 'mind seeps out onto the world' (Clark \& Chalmers 1998).

${ }^{7}$ See, for example, the debate between Honneth and Butler (Honneth 2012), or between Clark and Chemero (Chemero 2009), which would have gained considerably from taking seriously anthropological material concerning personhood. I can only agree in this matter with Monica Konrad (2005: xi).

${ }^{8}$ See, for example, the collection of essays on naming edited by Vom Bruck and Bodenhorn (2009) or the one edited by Tooker and Conklin (1984).

${ }^{9}$ I was especially influenced by the writings on the topic by Alleton (1993), Cohen (1994), Lévi-Strauss (1966), Mauss (1985 [1938]), Segalen (1980), and Zonabend (1984).

${ }^{10}$ Mauss 'The soul, the name and the person' (1971 [1929], II: 107), a comment on a conference by Lévy-Bruhl, where the sociologist declares that Franz Boas's (1897) material on Kwakiutl naming was what led him to think over the issue of personhood. 
${ }^{11}$ This is the case even where there is an avoidance of definitive names during early childhood. The process of personal naming accompanies the child from the beginning of language learning and is mediated by learning the use of personal pronouns.

${ }^{12}$ Escola Municipal Augusta Messias Guimarães, Valença; Colégio Perspectiva, Valença; Escola Estadual Menandro Menahim, Una; Escola Municipal Alice Fuchs de Almeida, Una; Colégio de São José, Una. I must thank in particular Euzedir Vaz Galvão for her support in mediating these contacts.

${ }^{13}$ I take this opportunity to thank Ulla Macedo and Inês Ponte for their excellent work, respectively in Valença and Una in 2005, 2006, and 2007.

${ }^{14}$ These add up to 246 , since we left out the three cases where the students responded exclusively to nickname attribution (all school mates) and the three responses that are unidentifiable.

${ }^{15}$ None of the 252 students made any reference to legal adoption, which confirms our fieldwork observation that, whilst fostering is very common in this region, legal adoption is correspondingly rare.

${ }^{16}$ As Paul Harris insists, '[C]hildren and adults alike are equipped to set reality aside and to take the point of view of a protagonist situated in an imagined landscape' (2000: 54).

${ }^{17}$ This includes two cases where she is depicted but the father is said to be the namer.

${ }^{18}$ There are 100 on his own, 13 jointly with the mother, and 5 where he is present but the mother is said to be the namer.

${ }^{19}$ As the father is 'the best painter', the drawing represents the world-famous video game character Super Mario (created by Nintendo) painting the word 'Church' on the façade of a building.

${ }^{20}$ The fact that, in this passage, Derrida has in mind Jewish circumcision only helps us better to see the evidence of a violence that was always, in any case, implicit in naming.

${ }^{21}$ Derrida, too, insists that affect 'can never be repressed in the unconscious but only suppressed and displaced in another affect' (1995: 28, original emphasis).

\section{REFERENCES}

Alleton, V. 1993. Les chinois et la passion des noms. Paris: Aubier Montaigne.

Almeida, H.B. 2003. Telenovela, consumo e gênero: 'muitas mais coisas'. Bauru: Edusc.

ANOlli, L., R. Ciceri \& G. Riva 2002. Say not to say: new perspectives on human miscommunication. Amsterdam: IOS Press.

Arendt, H. 1958. The human condition. Chicago: University Press.

BARKer, J. 2010. The varieties of Melanesian Christian experience: a comment on Mosko's 'Partible penitents'. Journal of the Royal Anthropological Institute (N.S.) 16, 247-9.

BlackWOod, E. 2005. Wedding bell blues: marriage, missing men, and matrifocal follies. American Ethnologist 32, 3-19.

BLOCH, M. 2008. The objects of evidence. Journal of the Royal Anthropological Institute (N.S.) Special Issue: The objects of evidence: anthropological approaches to the production of knowledge (ed.) M. Engelke, S1-21.

Boas, F. 1897. The social organization and the secret societies of the Kwakiutl Indians. Washington, D.C. (available on-line: $h t t p: / / w w w . a r c h i v e . o r g / d e t a i l s / c i h m \_14300$, accessed 1 November 2012).

BRÅTEN, S. (ed.) 1998. Intersubjective communication and emotion in early ontogeny. Cambridge: University Press/Maison des Sciences de l'Homme.

Butler, J. 2001. Giving an account of oneself. Diacritics 31: 4, 22-40.

2012. Taking another's view: ambivalent implications. In Reification and recognition: a new look at an old idea, A. Honneth, 97-119. Oxford: University Press.

Carneiro da Cunha, M. 2009 [1978]. De amigos formais e companheiros. In Cultura com aspas e outros ensaios, 51-8. São Paulo: Cosac \& Naify.

Chemero, A. 2009. Radical embodied cognitive science. Cambridge, Mass.: MIT Press.

ClARK, A. 1997. Being there: putting brain, body, and world together again. Cambridge, Mass.: MIT Press. \& D.J. Chalmers 1998. The embodied mind. Analysis 58, 10-23.

Conen, A. 1994. Self-consciousness: an alternative anthropology of identity. London: Routledge.

Derrida, J. 1995. Archive fever (trans. E. Prenowitz). Chicago: University Press.

Douglas, M. 1995. The cloud god and the shadow self. Social Anthropology/Anthropologie Sociale 3: 2, 83-94.

Duranti, A. 2008. Further reflections on reading other minds. Anthropological Quarterly 81, 483-93.

Errington, F. \& D. Gewertz 2010. Expanding definitions, contracting contexts: a comment on Mosko's 'Partible penitents'. Journal of the Royal Anthropological Institute (N.S.) 16, 250-2.

FonseCA, C. 2000. Família, fofoca e honra: etnografia de relações de gênero e violência em grupos populares. Porto Alegre: Ed. UFRGS. 
Fortes, M. 1973. On the concept of the person among the Tallensi. In La notion de personne en Afrique noire: actes $d u$ colloque international sur 'La Notion de personne en Afrique noire' (ed.) G. Dieterlen, 283-319. Paris: Éditions CNRS.

Fox, R. \& A. Gingrich 2002. Anthropology, by comparison. London: Routledge.

Hammond-Tooke, W.D. 1963. Kinship, locality and association: hospitality groups among the Cape Nguni. Ethnology 2, 302-19.

HARris, P.L. 2000. The work of the imagination. Oxford: Blackwell.

Honneth, A. 2012. Reification and recognition: a new look at an old idea. Oxford: University Press. Johnston, M. 2010. Surviving death. Princeton: University Press.

KANDEL, E.R. 2006. In search of memory: the emergence of a new science of mind. New York: Norton.

KNAUFT, B.M. 2010. Beyond polarization and partition in Melanesian anthropology: a comment on Mosko's 'Partible penitents'. Journal of the Royal Anthropological Institute (N.S.) 16, 244-6.

Konrad, M. 2005. Nameless relations: anonymity, Melanesia and reproductive gift exchange between British ova donors and recipients. New York: Berghahn.

Lévi-Strauss, C. 1966. The savage mind. London: Weidenfeld \& Nicolson.

Levinas, E. 1971. Totalité et infini: essai sur l'extériorité. Paris: Livre de Poche/Kluwer Academic.

LofTis, S.F. 2009. Attacking the canon through the corpse: cannibalism and surrogation in Hamletmachine. In Text and presentation, 2009 (ed.) K. Gounaridou, 81-93. Jefferson, N.C.: MacFarland \& Co.

Lopes da Silva, A. 1986. Nomes e amigos - da prática Xavante a uma reflexão sobre os Jê. São Paulo: FFLCH-USP. McCallum, C. 2005. Racialized bodies, naturalized classes: moving through the city of Salvador da Bahia. American Ethnologist 32, 100-17.

Marcelin, L.H. 1996. L'invention de la famille afro-américaine: famille, parenté et domesticité parmi les noirs du Recôncavo da Bahia, Brésil. Doctoral thesis, Rio de Janeiro, Museu Nacional, Universidade Federal do Rio de Janeiro.

Martins, H. 1974. Time and theory in sociology. In Approaches to sociology: an introduction to major trends in British sociology (ed.) J. Rex, 246-94. London: Routledge \& Kegan Paul.

Matos Viegas, S. De 2007. Terra calada. Rio de Janeiro: 7 Letras.

Mauss, M. 1971 [1929]. El alma, el nombre y la persona. In Institución y Culto: Representaciones colectivas y diversidad de civilizaciones, 105-108. Barcelona: Barral.

1985 [1938]. A category of the human mind: the notion of person; the notion of self (trans. W.D.

Halls) in The category of the person: anthropology, philosophy, history (eds) M. Carrithers, S. Collins \& S. Lukes, 1-25. Cambridge: University Press.

Mosкo, M. 2010a. Partible penitents: dividual personhood and Christian practice in Melanesia and the West. Journal of the Royal Anthropological Institute (N.S.) 16, 215-40.

2010 b. Partible penitents: a response to comments. Journal of the Royal Anthropological Institute (N.S.) 16, 253-9.

Needham, R. 1954. The system of teknonyms and death-names of the Penan. Southwestern Journal of Anthropology 10, 416-31.

Pina-Cabral, J. DE 1986. Sons of Adam, daughters of Eve: the peasant worldview of the Alto Minho (NW Portugal). Oxford: Clarendon Press.

1991. Os contextos da antropologia. Lisbon: Difel.

2002a. Between China and Europe: person, culture and emotion in Macao (LSE Anthropology Series

74). London: Berg; New York: Continuum.

-2002b. Dona Berta's garden: reaching across the colonial boundary. Etnográfica VI, 77-91.

2003. O homem na família: cinco ensaios de antropologia. Lisbon: Imprensa de Ciências Sociais.

2005. La soglia degli affetti: considerazioni sull'attribuzione del nome e la costruzione sociale della persona. Antropología 5, 151-72.

2007. Recorrências antroponímicas lusófonas. Etnográfica 12, 237-62.

2010a. Xará: namesakes in Southern Mozambique and Bahia (Brazil). Ethnos 73, 323-45.

$2010 b$. The door in the middle: six conditions for anthropology. In Culture wars: context, models and anthropologists' accounts (eds) D. James, E. Plaice \& C. Toren, 152-69. Oxford: Berghahn.

- 2010c. The dynamism of plurals: an essay on equivocal compatibility. Social Anthropology/ Anthropologie Sociale 18: 2, 1-15.

2011. Afterword: what is an institution? Social Anthropology/Anthropologie Sociale 19: 4, 475-94. 2012. The functional fallacy: on the supposed dangers of name repetition. History and Anthropology 23, $17-36$.

Roach, J. 1996. Cities of the dead: circum-Atlantic performance. New York: Columbia University Press. 
Robbins, J. 2010. Melanesia, Christianity, and cultural change: a comment on Mosko's 'Partible penitents'. Journal of the Royal Anthropological Institute (N.S.) 16, 241-3.

SAHLins, M. 2011a. What kinship is (part one). Journal of the Royal Anthropological Institute (N.S.) 17, 2-19. 2011b. What kinship is (part two). Journal of the Royal Anthropological Institute (N.S.) 17, 227-42.

SEgAlen, M. 1980. Le nom caché: la denomination dans le pays bigouden sud. L'Homme XX: 4, 63-76.

Sмith, R. 1996. The matrifocal family. London: Routledge.

Strathern, M. 1988. The gender of the gift. Berkeley: University of California Press.

Tomasello, M. 2008. Origins of human communication. Cambridge, Mass.: MIT Press.

Tooker, E. \& H. Conklin (eds) 1984. Naming systems. Washington, D.C.: The American Ethnological Society.

Toren, C. 1990. Making sense of history: cognition as social process in Fiji. London: Athlone. 1999. Mind, materiality and history: explorations in Fijian ethnography. London: Routledge.

Trevarthen, C. 1986. Development of intersubjective motor control in infants. In Motor development (eds) W.G. Wade \& H.T.A. Whiting, 209-61. Dordrecht: Martinus Nijhoff.

vom Bruck, G. \& B. Bodenhorn (eds) 2009. An anthropology of names and naming. Cambridge: University Press.

Webster, D.J. 2009 [1976]. A sociedade Chope: indivíduo e aliança no sul de Moçambique (1969-1976). Lisbon: Imprensa de Ciências Socials.

Winnicott, D.N. 1971. Playing and reality. London: Routledge.

Zonabend, F. 1984. Prénom et identité. In Le prénom: mode et histoire. Entretiens de Malher 1980 (eds) J. Dupâquier, A. Bideau \& M.-E. Ducreux, 23-35. Éditions EHESS.

\section{Un noyau d'affects : nommer et être nommé à Bahia (Brésil)}

Résumé

Le présent article est une étude des noms personnels basée sur des dessins réalisés par des élèves du secondaire dans deux petites villes sur la côte de Bahia (Brésil) et représentant les personnes qui leur ont donné leur nom. L'auteur explore la relation entre celui qui donne le nom et celui qui est nommé comme un lien d'identité continue, créé par des processus imaginatifs de substitution proches du «faire semblant ». Au début de son ontogenèse, la personne est constituée par une série de mutualités d'être qui finissent par constituer un noyau d'affects. Le présent article se veut une contribution à une meilleure compréhension des processus de construction de la personne dans le contexte de la relationalité humaine.

João de Pina-Cabral is Professor of Social Anthropology and head of the School of Anthropology and Conservation at the University of Kent, Canterbury. His work as a social anthropologist has focused on family and kinship, personal naming, ethnicity in postcolonial contexts, and religion and belief. He has carried out extensive fieldwork and published on the rural population of the Alto Minho (northwestern Portugal), on the Eurasian population of Macau (southern China) and, more recently, on coastal Bahia (Brazil).

School of Anthropology and Conservation, Marlowe Building, University of Kent, Canterbury CT2 7 NR, UK. J.Pina-Cabral@kent.ac.uk 